\title{
AN OVERVIEW OF RUSSIAN NORMATIVE DOCUMENTS ON TAXATION ISSUES FOR MAY-JUNE 2015
}

\author{
L.Anisimova
}

Over the period under consideration, the RF Ministry of Finance released ${ }^{1}$ the Main Directions of Tax Policy for 2016 and the Planning Period 2017-2018 (hereinafter - Main Directions), where it is stated that no increase in the tax load on the economy is intended, and measures are envisages which, in the opinion of the document's authors, will be designed to boost Russia's economic development. The prospects for business development in Russia were also the main theme of the St Petersburg International Economic Forum (SPIEF) (18-20 June 2015).

Over the period under consideration, output in the Russian economy dropped nearly $5 \%$ on the same period of last year. At the same time, it became possible to halt the decline in the amount of Russia's gold and foreign currency reserves (in May, this index rose to $\$ 361 \mathrm{bn})^{2}$, and the inflation rate became significantly lower. The RF Central Bank predicts that it may be possible to gradually lower the key rate, though it still remains at the high level of $11.5 \%$. The RF Minister of Finance noted that organizations began to display profit (the economic sanctions and the ruble's weakening produced a situation where cash flows are becoming increasingly confined to Russia's domestic space only: many people can no longer afford foreign travel and have fewer opportunities to buy imported goods (or work, or services), and so they consume instead domestic products, work, or services), and the amount of residuals in individual bank accounts has increased. Meanwhile, the investment index shows no growth, and the amount of regional budget debt to banks does not decline. Credits are still unavailable to producers. According to some experts, the Russian economy is faced with the threat of a protracted stagnation. At the same time, the cheapness of Russia's market and the anti-recession package designed to provide support to small and medium-sized businesses - that is, the 'basis' stratum of entrepreneurs - have attracted the attention of potential investors, which explains their interest in the St Petersburg International Economic Forum's agenda.

The recommendations of eminent economists notwithstanding, the RF Government is reluctant to run the risk of attempting structural reform in view of the forthcoming FIFA World Cup to be hosted by Russia, evidently fearing the intensification of negative social phenomena typical of the periods of such transformations. The range of the necessary short-term goals has been graphically described by former RF Minister of

1 See the RF Ministry of Finance's official website, 3 June 2015. 2 Russia's reserves increased by $\$ 5 b n$ over the course of one week. See lenta.ru/news/2015/06/11/reserve5bln
Finance Alexei Kudrin: to raise the retirement age; to improve the performance of state corporations and the procedure of revenue redistribution in favor of the regions, in order to enable them not only to invest in the social sphere, but also to launch other investment projects. In Kudrin's opinion, 'the military-industrial complex will not be able to become a driver of economic growth because it is pegged to government defense orders and does not respond to market signals'. However Kudrin believes that, at present, 'mutual exchange of technologies between the civil and military sectors is taking place all over the world'. Import substitution, in his opinion, will lead to breakthroughs in some industries, it must be promoted, but the currently adopted program cannot ensure a large-scale modernization of the national economy. 'What we need is competitive import substitution under open market conditions, and not as a form of enclosure, isolated from the world economy'.

The policy of 'retaliatory sanctions', should it be maintained on a long-term basis, may indeed result in the Russian market's isolation, followed by a distorted view of the true competitive capacity of our national economy. Russia must gradually depart from its orientation towards retaliatory economic sanctions: the reduced purchasing capacity of the population can serve as a natural protection of the domestic market from imported goods, which will not be sold in the Russian market at prices lower than their prices on the world market ${ }^{3}$. On the contrary, the support of production entities with low competitive capacity by means of keeping the 'trade curtain' in place over a long time will prevent domestic producers from accurately determining the market value of their products, and so instead of the 'purifying effect' of the crisis we

3 At the same time, the access to the Russian market of the goods (or work, or services) produced by foreign state monopolies should be restricted, because the relevant foreign governments will maintain their prices at a low level. Thus, the competitive balance in Russia's domestic market will be upset, and the cash flows will be reoriented towards foreign markets. 
may end up with conservation of backward industries, which will consume all our inner resources. It should be added though that, if the interest rates on loans do not go down to the level of the world market, to simply open the market to imports of goods (or work, or services) will mean to push away from it domestic producers, as it used to be the case previously, before the economic sanctions were introduced. If the RF Central Bank should keep the key rate for an unnecessarily long period, Russian producers will be unable to take advantage of the 'cheap' and 'non-competitive' market, and so the market will be divided between those in possession of 'hot money'.

The RF Government is attempting to compensate for the necessarily cautious approach of the RF Central Bank to regulation in the monetary and foreign exchange spheres by relying on the traditional principle: no money to be allotted - so tax exemption should be granted. Once again, the term 'stimulatory tax policy' emerged, its limitation being that instead of reducing the overall tax load by cutting government expenditure in condition of the taxation system's neutrality and fair distribution of the tax load between all taxpayer categories, a number of 'targeted' exemptions are introduced only for selected taxpayer categories.

To be just, it should be admitted that many provisions of the Main Directions are worthy of unconditional support. This is true of the proposal that tax exemptions should be introduced exclusively for a limited period of time - no longer than 5 years, with the possibility of its subsequent prolongation depending on the consequences that they have led to. By 2018, the federal exemptions from regional and local taxes will be reduced by $85 \%$. In the long run, it is planned that no new exemptions from regional and local taxes should be introduced at the federal level. At present, according to the Federal Tax Service (FTS), the 'taxrelated' budget expenditures (so called because of the money lost as a result of the exemptions) amount to approximately $\mathrm{Rb} 2$ trillion ${ }^{1}$.

Another way to reduce the financial load on businesses can be that of bringing down the amount of mandatory non-tax payments. As estimated by the RF Ministry of Economic Development, as a result of a moratorium on any further raise of the rates of certain non-tax payments until 2019, businesses will be able to save up to $\mathrm{Rb} 1.8$ trillion, or approximately $3 \%$ of GDP. In order to achieve this goal, it is intended that during the planning period, the additional index of Russian domestic 'fiscal' load should be introduced, which will reflect the amount of taxes paid, as well as some types of non-tax payments; while the entire category of nontax payments and the policy with regard to their regu-

1 Section 4 of the Preamble to the Main Directions,. lation should stipulated in the Main Directions of Tax Policy for each relevant three-year period ${ }^{2}$.

Equally praiseworthy is the RF Government's intention to once again deal with the issue of the budgetary system's optimization or, more precisely, to determine the positive effects of the replacement of the Single Social Tax by a system of insurance contributions to government off-budget social funds. This issue has become especially important in connection with the transition to a new point-based pension allocation system. The RF Ministry of Finance believes it feasible to continue to analyze the performance of the existing system, while assessing just how burdensome the new system is going to be both for taxpayers (by introducing different systems for payment administration and multiple supervisory bodies) and for the government (by increasing the number of civil servants) ${ }^{3}$.

No doubt, the positive feature of the Main Directions is that they offer a very detailed description of the measures designed to coordinate the tax policy of the Russian Federation with the policies of other states in the framework of the Organization for Economic Cooperation and Development (OECD) ${ }^{4}$. Thus, in 2018, Russia plans to join the multilateral agreement on automatic financial information exchange envisaged by International Financial Reporting Standards (IFRS) elaborated by the $O E C D^{5}$. It is also intended that the RF Tax Code should be augmented by provisions whereby the loans granted by a core company to its affiliation by way of recapitalization are to be treated as investment, and that the tax levied on the interest received on such loans should be the same as that levied on dividends $s^{6}$.

The question as to how the transfer of funds in the framework of the relations between a parent company and its affiliation should be treated is becoming very important. In the Russian Federation, the appeal of some high-profile legal firms to the Arbitration Court of Moscow District concerning the definition and treatment of the royalties paid by Oriflame Cosmetics LLC to its parent company Oriflame got a lot of publicity. Lawyers define such royalties as costs, while tax authorities do not approve their deduction from the tax base, explaining that Oriflame Cosmetics LLC is a representative of Oriflame, and so the payment of royalties 'to itself' by that company should be regarded as transfer to another jurisdiction of income received in

2 Main Directions, Item 14 of Section III.

3 Main Directions, Item 13 of Section III.

4 The implementation of the OECD Action Plan on Base Erosion and Profit Shifting - BEPS (OECD/G20) (the OECD/G20 BEPS Project), approved by the heads of states and governments of the Group of Twenty under Russia's chairmanship in September 2013.

5 Main Directions, Item 9.1 of Section III.

6 Main Directions, Items 2.6 and 9.2 of Section III. 
RF territory ${ }^{1}$. In terms of economics, the tax authorities are evidently right, but in a legal sense the disputable norm stipulates in the RF Tax Code needs to be formulated more accurately.

In the framework of cooperation with the OECD, improvement of the taxation rules applied to the profit of controlled foreign companies ${ }^{2}$ and transfer pricing ${ }^{3}$ are among the most important areas of development. The former has to do with the so-called anti-offshore legislation, namely the issue of inclusion in the tax base of a Russian resident of the undistributed profit gene-rated by the foreign company controlled by that Russian resident. The controlling persons of a foreign company are deemed to be those persons whose share in that company amounts to more than $25 \%$, or to more than $10 \%$ if the aggregate share of all the persons recognized as being RF tax residents amounts to more than $50 \%$. In Russia, the profit generated by a controlled foreign company should be entered in the tax records for a given tax period for the purpose of levying the tax on profits of organizations or personal income tax if it amounts to more than $\mathrm{Rb} 10 \mathrm{~m}$ (in 2015 - to more than Rb 50m, in 2016 - to more than Rb $30 \mathrm{~m})^{4}$. In the second case, the income received in the territory of one state (Russia) is transferred, tax-free, into the territory of a tax haven by means of deliberately overestimating the costs incurred in a given deal.

The measures envisaged in the Main Directions may be roughly grouped as follows: first, measures that involve the granting of exemptions from VAT and excises to big taxpayers; second, exemptions granted to small and medium-sized businesses, as well as general exemptions that usually result in reduced revenues received by regional and local budgets - and so these are formulated as the right of regional and local authorities to reduce tax rates (profits tax, property taxes, etc.); third, decisions concerning the abolition or suspension of previously granted tax exemptions; four, other innovations.

The measures designed to support big businesses.

In the framework of anti-recession measures and measures designed to support exports, it is intended that biggest taxpayers should be made exempt from the payment of excises on goods to be exported, without bank guarantees being granted to them ${ }^{5}$.

Some slackening of the rules is also planned with regard to control over transfer pricing in the course

\footnotetext{
1 Gazeta RBC (stated as the author). Lawyers saw a threat to the entire business community in the Oriflame vs. the FTS case. See rbcdaily.ru/economy/562949995441837?utm source=infox\&utm medium=obm\&utm_campaign=news от 04.06.2015.

2 Main Directions, Item 9.3 of Section III.

3 Main Directions, Item 9.4 of Section III.

4 Annex 1 to the Main Directions.

5 Main Directions, Item 2.8 of Section III.
}

of domestic transactions. It is expected that control should be exercised only over transactions to the value of more than $\mathrm{Rb} 2-3 \mathrm{bn}$, with subsequent periodic indexation depending on the inflation rate ${ }^{6}$.

It is envisaged that, with regard to goods (or work, or services) earmarked for exports, it is planned that the amount of incoming VAT may be deducted ${ }^{7}$ (in this connection it should be reminded that nearly half of the federal budget is generated by exports of hydrocarbons, which are extracted predominantly by raw materials monopolies). The rate of VAT on exports is $0 \%$. So, we believe that thus, on the basis of the RF Tax Code, a channel is formed through which, in disregard of existing budget legislation and outside of the standard practice of granting subsidies from the budget, incoming VAT will be directly recompensed (that is, refunded or set off). To those producers that do not export their product, the old procedure will be preserved whereby, if a zero rate is applied, the amount of incoming VAT will be charged to production costs. We believe that such direct payments from the budget applied to exports of goods (or work, or services) may be deemed, in the framework of the WTO, to be subsidies. In this case, the refunds will be withdrawn to the budgets of other states.

Section 4 of the Main Directions envisages that a taxpayer company may be granted the right to an application-based VAT recovery procedure against a surety provided by its parent company, if the aggregate amount of VAT, excises, tax on profits of organizations, and mineral resource extraction tax (MRET) paid by that parent company over the three calendar years preceding the year during which the application for the right of the said VAT recovery procedure, is no less than $\mathrm{Rb} 10 \mathrm{bn}$.

In the Main Directions it is envisaged that stimulation of the economy is to be achieved through expanding the rights of subjects of the Russian Federation and providing them with additional instruments for implementing economic development policy in their respective territories. These declarations, however, proved to be controversial when implemented in actual practice, because the rights of RF subjects are being expanded in the main by enabling their authorities to reduce tax rates - evidently to make the regions compete with one another by trying to become more attractive to investors. It is also envisaged that a subject of the Russian Federation may be granted the right to reduce, to $10 \%$, the rate of tax profit of organizations applied to that part of the tax payment which is to be transferred to the budget of that subject of the Russian Federation; this right may be exercised in regard of newly created

6 Main Directions, Item 2.9 of Section III.

7 Main Directions, Item 2.10 of Section III. 
industrial enterprises making capital investment (it is also envisaged that, for such taxpayers, the rate of tax on profits of organizations applied to that part of the tax payment, which is to be transferred to the federal budget, may be reduced to $0 \%$ ).

However, as far as the investment contracts concluded in the framework of Federal Law of 31 December 2014, No 488-FZ 'On the Industrial Policy of the Russian Federation' are concerned, it is planned that the rights of subjects of the Russian Federation should be limited, in accordance with the legislatively consolidated norm to the effect that the Federation's subjects may not, until 2025, raise the rate of profits tax applied to its 'regional' part by more than $2 \%$ above the rate of initially established for the investor who is party to an investment contract. The depreciation deductions from the value of equipment belonging to depreciation groups No 1-7 may be charged, in the framework of an investment contract, with the coefficient 2 applied to the established depreciation norm ${ }^{1}$.

Other legislative innovations, like the permission to write off property to the value of up to $\mathrm{Rb} 80,000$ 100,000 by charging it to costs in a one-time procedure, are not oriented to the goal of replenishing regional and local budgets, either ${ }^{2}$.

In the framework of special tax regimes it is expected that the right to 2-year 'tax holidays' (granted under the patent system and the simplified taxation system) should be extended to the sphere of household services; the patent system will also be expanded, by including into it some other types of permitted activities ${ }^{3}$.

It is intended to raise 1.2-1.5 times the ceiling for the amount of proceeds, on which advance payments of tax on profits of organizations may be transferred on the basis of quarter-end financial result ${ }^{4}$.

Among the other measures outlined in the Main Directions, the following ones should be noted. The RF Ministry of Finance did not support the proposal that advance payments should be made exempt from VAT, because this would have been to the detriment of buyers - should this rule have been introduced, they would have been deprived of the right to a setoff (or refund) of the amount of VAT paid as part of their advance payment ${ }^{5}$. In the Main Directions, no indexation of the excise rates in 2016-2017 is envisaged, either ${ }^{6}$. The RF Ministry of Finance, in order to reduce the administrative load on businesses, suggests that the accounting (financial) reports of organizations,

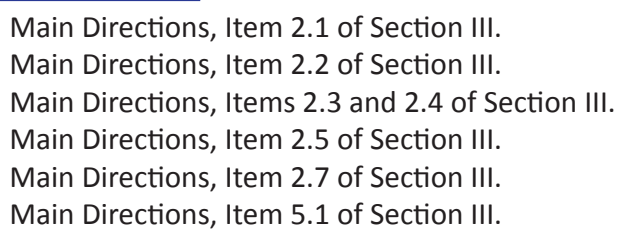

that have to be submitted by them to a tax agency, should be taken off the list of items deemed to be kept secret; simultaneously, organizations are relieved of the responsibility to submit these reports once again to state statistics agencies ${ }^{7}$.

A specific category of innovations introduced into tax legislation is represented by those exemptions that are to be suspended, because their impact on the economy has turned out to be dubious. For example, this is true of the proposal concerning the prolongation, until 1 January 2019, of the period of suspension, for the duration of the year 2015, of the enactment of agreements concerning the creation of consolidated taxpayer groups (CTGs) registered by tax agencies ${ }^{8}$, in order to additionally elaborate the mechanism of reforming CTGs, so that it 'should conduce to just distribution of the revenues generated by tax on profit of organizations between regional budgets, while precluding any uncertainty in the course of planning the budgets of subjects of the Russian Federation'.

One example of a tax exemption introduced without sufficient substantiation is cited by the RF Ministry of Finance in its analysis, in the Preamble to the Main Directions, of the reasons for its refusal to make fully exempt from property tax the newly acquired movable property entities.

Now let us further clarify the essence of the problem. In accordance with the RF Tax Code (Item 1 of Article $374)$, the object of taxation, for Russian organizations, is deemed to be movable and immovable property entities listed on a taxpayer's balance sheet as fixed assets. Shortly before the onset of the crisis, the lawmakers had decided, by way of giving an additional impetus to the modernization and technological upgrading processes, to introduce an exemption from property tax for movable property entities. This exemption was applied, among other things, also to the instances of entry into a balance sheet of movable property entities received as a result of a company's reorganization, or from a related party. Later on, as the crisis began to evolve, that exemption was modified by introducing amendments to Articles 374 and 381, whereby from 1 January 2015 the fixed assets belonging to Depreciation Groups 1 or 2 were to be made exempt from property tax ${ }^{9}$, with the exception of those movable property entities that had been entered into the organization's records as a result of the following acts: reorganization or liquidation of legal entities; transfer of property, including its acquisition, between related parties. Thus, from 2015 onwards, property tax was once again to be levied on

7 Main Directions, Item 7.2 of Section III.

8 Main Directions, Item 8 of Section III.

9 These entities comprise property with useful life of 3 years or less. 
those movable property entities that had been entered into records over the course of tax periods 2013-2014 as result of reorganization or receipt (or acquisition) from related parties, with the exception of entities belonging to Depreciation Groups 1 or 2 .

The recommendations offered by the RF Federal Tax Service to its territorial administrations are also of interest; these are stated in Letter of the RF Ministry of Finance and the RF Federal Tax Service, No BS-4-11/9319 of 1 June 2015, as follows: '...the Administrations of the FTS of Russia supervising subjects of the Russian Federation, and the Inter-regional Inspectorates of the RF Federal Tax Service supervising biggest taxpayers, are assigned the task of organizing the process of identification of those taxpayers whose tax base for tax on property of organizations diminished over the course of tax periods 2013-2014 due to the intended withdrawal from the taxation system of movable property entities, and no corresponding increase in their tax base took place in 2015. These taxpayers should be made familiar with the information on the relevant alterations to tax legislations, and in 2015, a monitoring procedure should be carried out, with an upward adjustment of the mean value of their taxable property, and in those cases when no upward adjustment is made, the relevant organizations should be made subject to a pre-audit analysis, so that a proper decision could be made with regard to placing them on the list of planned B on-site tax audits'.

So, it appears that when the lawmakers were introducing this exemption, they were well aware of the possibility that related organizations would transfer equipment items between themselves in order to avoid the tax; and now tax inspectors are looking for these items to avoid the aggregate (nationwide) loss of revenue generated by property tax ${ }^{1}$. We believe that such experiments with the wording of the RF Tax Code make the process of tax administration more expensive, without any proper justification, and worsen the performance of tax agencies.

Among the other normative documents adopted over the period under consideration, note the following.

1. By Federal Law of 8 June 2015, No $140-$ FZ alterations are introduced to the legislative acts whereby the legal aspects and procedures of voluntary declaration, by Russian taxpayers, of their assets and accounts (or deposits) opened or placed with foreign banks are to be regulated ${ }^{2}$.

1 The loss generated by this tax exemption, as estimated by the Federal Tax Service, is about $0.1 \%$ of GDP.

2 This law is also known as the law on the 'amnesty for individual capital', although it addresses violations of tax legislation.
The objects to be thus declared are explained in Article 3 of the Law: a) land plots, other immovable property entities, transport vehicles, securities, shares in the capital of Russian and foreign companies; b) controlled foreign companies (CFC); c) accounts opened by a taxpayer with banks situated abroad; d) accounts opened with banks situated abroad, in respect of which the taxpayer acts as a beneficiary.

In accordance with Item 6 of Article 3, the declarant should disclose, by way of a free-form text, information concerning the sources of acquisition (or the methods whereby the sources of acquisition have been formed) of the relevant property entities and deposited assets, as well as supply the documents in confirmation of the declarant's (and (or) the nominal owner's) rights in respect of the property entities specified in the declaration.

In accordance with Article 4, if a declaration concerning property is submitted, the declarant should be relieved of criminal, administrative and tax responsibility. These guarantees are also to be extended to those persons who, in accordance with the directive documents in the framework of a CFC have been performing their organizational- directive or administrativeeconomic functions in respect of the entities entered into the declaration. In accordance with Items 3 and 4 of Article 4, the fact of a declaration being submitted, as well as of the documents and (or) information attached to the declaration, and the information stated in the declaration and the documents and (or) information attached to the declaration, may not be used as the grounds for initiating criminal proceedings, or the commencement of proceedings against the declarant and (or) the nominal owner of relevant property for their violation of administrative and (or) tax legislation; nor may these be used as evidence in the framework of a criminal proceeding, or proceedings in a case of a violation of administrative and (or) tax legislation.

2. By Federal Law of 8 June 2015 , No $146-F Z$ 'On Introducing Alterations to Chapter 23 of Part Two of the Tax Code of the Russian Federation', the list of grounds for a taxpayer to be granted a tax deduction from personal income tax is extended. In addition to sale of property, stakes (or participatory shares) in the capital of economic societies, or their transfer in the form of an act of cession of property, the list is augmented by the instances of receipt of income in an event of a participant's withdrawal from an economic society, transfer of the property of a liquidated economic society, and reduction of the nominal value of a share in a charter capital of an economic society.

The wording of the provisions regulating the issue of implementation of double taxation agreements has 
been altered, by way of augmenting it with new provisions. Thus, in particular, the procedure for setting off in the RF of the amounts of tax paid in a foreign state is described in detail.

3. By Federal Law of 8 June 2015, No 150-FZ, alterations are introduced to the RF Tax Code in the part of taxation of the profit of controlled foreign companies (CFCs).

The alterations to the RF Tax Code have to do with the issues of taxation of CFCs, symmetrical adjustments to the taxation of controlled transactions, as well as the tax consequences of capital amnesty.

The Federal Law introduces adjustments to the notion of a controlled foreign company. Now, to the category of CFCs, in addition to companies, also belong those foreign structures that operate without creating a legal entity, whose controlling entity is a resident of the Russian Federation. The notion of a controlling entity encompasses not only those persons that hold stakes in a company's capital, but also the persons who actually exercise control (or influencing the decision-making by the managerial bodies of a CFC) in their own interests and the interests of their families, and influencing the distribution of profit. It is the influence on the process of profit (or income) distribution and the right to withdraw the contributed property entities that is the principal determining feature of a controlling entity.

A taxpayer is not to be deemed to control a CFC, if the taxpayer's participation in the relevant foreign organization is effectuated exclusively through direct or indirect participation in a Russian public company.

The conditions for exempting the income of a CFC from taxation in the Russian Federation are stipulated more precisely (in particular, such exemption is granted to a not-for-profit organization; an organization created in accordance with legislation of the European Economic Community; to an active foreign company; to an active foreign holding company; to an active foreign sub-holding company; to a bank; to an insurance organization; to an entity participating in mineral resources extraction projects in the framework of product sharing agreements concluded with a foreign state, or a concession agreement, or a licensing agreement).

The conditions for an exemption from excise on export operations are specified (big taxpayers are granted the right to be exempt from the payment of excise without securing a bank guarantee).

It is established that a CFC enjoys the right to independently recognize itself as a tax resident of the Russian Federation, etc. 